\title{
Epidemiology of hospital-acquired infections at a tertiary care center in Lebanon
}

\author{
S Kanj", G Kamel, L Alamuddin, N Zahreddine, N Sidani, ZA Kanafani \\ From International Conference on Prevention \& Infection Control (ICPIC 2011) \\ Geneva, Switzerland. 29 June - 2 July 2011
}

\section{Introduction / objectives}

To describe the epidemiology of hospital-acquired infections (HAI) at the American University of Beirut Medical Center (AUBMC) between October 2007 and September 2010.

\section{Methods}

The Infection Control and Prevention Program (ICPP) at AUBMC conducts prospective targeted surveillance of device-associated infections in critical care areas (ventilator-associated pneumonia [VAP], catheter-associated urinary tract infection [CA-UTI], and catheter-related bloodstream infection [CR-BSI]). Device-associated infections are benchmarked against the rates published by the National Healthcare Safety Network (NHSN) and the International Nosocomial Infection Control Consortium (INICC). All HAIs are identified using the Centers for Disease Control and Prevention (CDC) definitions.

\section{Results}

VAP rates were highest in the intensive care unit (ICU) (13.2-15.5/1,000 ventilator days). The most common organisms causing VAP were $A$. baumanii, $P$. aeruginosa, and E. coli. The respiratory care unit (RCU) had the highest rate of CA-UTI (13.6-16.0/1,000 catheter-days), with $E$. coli and K. pneumoniae being the most common pathogens. CR-BSI were mostly caused by coagulasenegative staphylococci, and rates ranged from 9.2 to $15.5 / 1,000$ catheter days in ICU. The rates of devicerelated infections were in general higher than NHSN and comparable to INICC rates.

Internal Medicine/Infectious Diseases, American University of Beirut, Beirut, Lebanon

\section{Conclusion}

Active surveillance remains a critical step towards recognizing and preventing hospital-acquired infections. New infection control strategies should be implemented in order to decrease the rate of device-related infections in critical care areas. These strategies include educational activities, compliance with hand hygiene and the device bundles, proper training for healthcare workers, and continuous monitoring.

\section{Disclosure of interest}

None declared.

Published: 29 June 2011

doi:10.1186/1753-6561-5-S6-P242

Cite this article as: Kanj et al:: Epidemiology of hospital-acquired infections at a tertiary care center in Lebanon. BMC Proceedings 20115 (Suppl 6):P242.
Submit your next manuscript to BioMed Central and take full advantage of:

- Convenient online submission

- Thorough peer review

- No space constraints or color figure charges

- Immediate publication on acceptance

- Inclusion in PubMed, CAS, Scopus and Google Scholar

- Research which is freely available for redistribution

\section{() Biomed Central}

\section{Biomed Central}

